\title{
ROMANIAN SPA TOURISM: A COMMUNIST PARADIGM IN A POST COMMUNIST ERA
}

\author{
George Erdeli $^{\mathrm{a}}$, Ana Irina Dincă ${ }^{\mathrm{a} *}$, Aurel Gheorghilaş ${ }^{\mathrm{a}}$, Camelia Surugiu ${ }^{\mathrm{b}}$ \\ ${ }^{a}$ University of Bucharest, Faculty of Geography, 1, Nicolae Balcescu Avenue, o10041, Bucharest, Romania \\ ${ }^{\mathrm{b}}$ Romanian National Institute for Research and Development in Tourism, Bucharest, Romania
}

\begin{abstract}
Spa tourism is one of the oldest forms of tourism which continuously evolved in time as the leisure industry paradigm and the consumers' behavior changed. Similar to other countries in Central and Eastern Europe, spa tourism is an old phenomenon in Romania which expanded to the dimensions of a well defined tourism industry during the mass tourism period which also corresponded to the communism epoch. Although severely affected by the major political and socio-economic changes which occurred after the Revolution in 1989, this industry coexists with new emergent forms of tourism orienting, itself towards new dimensions embraced by the contemporary leisure consumerism (e.g. medical tourism, cosmetic treatments). Lying on considerable balneal and climate resources and displaying an important communist heritage both in physical terms (large and massive tourism structures) and in virtual and psychological terms (social supportive ticket granting system), Romanian spa tourism faces various challenges in the attempt to adapt in a new tourism era.
\end{abstract}

Key words: Romania, Spa tourism, Communist heritage, Post-socialist evolution.

\section{Introduction}

Spa tourism is one of the oldest types of tourism, developed since antiquity age, which evolved continuously and developed complex and various forms throughout different historical periods under the influence of political and economic systems, on the one hand, and of changes in the social options and tourists' interests regarding this type of tourism, on the other. As a constantly important part of tourism activity, spa tourism gained in time new variables, determined by the dynamic of leisure industry and by the evolution of consumers' behavior paradigm.

This study aims to define the main characteristics of the Romanian spa tourism, traditionally an important part of the national tourism market, due to the important resources discovered and valued since antiquity and developed to the dimensions of a real tourism industry during communism period, which tries to adapt to new market realities. This paper underlines the meaning of spa tourism, as a continuous multiphase paradigm, influenced by modern patterns of tourism consume and, at the

*Corresponding author:

Email: dincaanairina@gmail.ro same time, the matching of Romanian practices and types of destinations into it. The second part of the paper emphasizes the important role played by the communist heritage in the present resorts' landscape, especially through the pregnant mass hospitality structures and the social systems of consume, adapting too slowly to the new market demands. In this context, new strategies have recently been elaborated by the Government with the help of international experts, in order to help the industry adopt a more marketing oriented approach for its future development.

\section{The meaning of spa tourism}

The main function of spa tourism resorts is to provide health care service by using natural factors for medical cure in specialized structures and a pleasant environment. Spa locations can differ, to a great extent, from a simple spa hotel until a real tourism resort with different spa profiles. Within the tourism market, a clear distinction between medical and balneal tourism can be made, as the first is mainly focused on treatments and cure of an already diagnosed illness, its extreme form being the surgical intervention, and the second is focusing both on 
prevention and on prophylaxis and rehabilitation comprising less invasive procedures (after Dincă, 2006). It is the balneal tourism, however, that considers natural factors, mainly mineral and/or thermal waters to be the main healing trigger for different affections, often appealing to other traditional natural products such as mud, gases, plants etc. . Medical tourism appeals to balneal resources as a complementary solution next to pharmaceutical products and other allopath healing techniques. According to the European Spa Association (ESPA) „the essential framework of the spa industry is based mainly on the use of natural resources (including a healthy climate) with an important contribution from medical care and a comprehensive approach to therapeutic stays". The definition describes what the traditional Romanian balneal-climate tourism. The use of certified and legally state recognized local natural remedies would be among the first conditions ESPA mentions for the existence of health resorts and spa facilities. Often their profile differs according to the type of resources. The organization also remarks the fact that most spas are located in a beautiful landscape, offering optimal conditions for relaxations and that they should benefit more than other settlements of the environmental protection. It is generally agreed, in the scientific literature, that the existence of health and spa resorts is at least "in part related to the availability of suitable natural resources including mineral springs or attractive amenity landscapes or climate" (Hudson, 2003).

Among the curative resources for spa tourism, defined by worldwide reference organizations, one may mention: springs with medicinal water for both internal and external therapeutic use; healing gases; spas, spa facilities and health resorts at the seaside inevitably connected to thalassotherapies; peloids used in spas, health resorts and spa facilities, produced during geological and/or biological processes and used in treatments in form of compresses, packs or also in bath-tubs; bioclimate/healing climate which define according to different associations a separate health resort type and Kneipp therapy, often mixed with elements of the Priesnitz therapy, and frequently applied in spas and health resorts though often only in parts. Due to modern medical techniques and new orientations of leisure industry and to new patterns of behavior adopted by the contemporary tourist ESPA also admits that „today spa visits, health tourism, wellness, beauty and fitness programmes, regenerative, reconditioning and relaxation stays, are all dynamically growing products and tourist product packages which, combined with all-inclusive accommodation, catering, entertainment, sporting and other activities, are responding to the most challenging demands of individual tourists, as well as tourist offices and agencies" (http://www.visitspas.eu/european-spa-industry/).

The International Spa Association (ISPA) admits on its turn the existence of a variety of professional services, offered as spa products, for which clients, not necessarily tourists, may opt for according to their needs. The organization identifies primary types of spas: the club spa (with a primary purpose in fitness); the cruise ship spa; the day spa (offering many of the same services and procedures as cosmetic spas); the destination spa (a facility which attracts spa goers for a period of stay guiding them to develop healthy habits through a comprehensive complex program); the medical spa (as a full-time licensed professional health care facility providing comprehensive medical and wellness care by integrating spa services, as well as traditional, complimentary and/or alternative therapies and treatments); the mineral springs spa (a spa offering an on-site source of natural mineral, thermal or seawater used in hydrotherapy treatments) and the resort/hotel spa (providing professionally administered spa services, fitness and wellness components and spa cuisine menu choices for travelers away from home and sometimes for local clientele) (after http://www.experienceispa.com).

The Romanian Master Plan for the Development of Spa Tourism (2009), as the reference national strategy for this domain mentions that health tourism has nowadays several segments, namely: medical tourism, balneal tourism, thalasotherapy, hydrotherapy, wellbeing/spa and fitness, displaying different functions from prevention to healing and recreation. In this way the healing treatment function is displayed only by medical and balneal tourism, whereas the recreational aspect is fulfilled only by the last three. Almost all the forms, except from medical tourism and fitness, play the preventing role. Consequently, health tourism seems to be a more proper denomination for what used to be traditionally named as spa/balneal-climate tourism and for the whole range of the present, above mentioned manifestations. Moreover, beside the great variety of health resorts and facilities, spa tourists are also various "ranging from guests in search of a rest to the truly ill" (ESPA). Therefore, tourism demand justifies the various offer of services in the resorts "including all forms of prevention (primary, secondary and tertiary) up to rehabilitation and the treatment of chronic diseases" (ESPA) as today spas are frequented by both young and old tourists, by singles and families with children.

Another recent trend refers to the preference of business tourism, especially conferences and congresses, for spa structures. Mountain and climate spa resorts oriented as well to a greater extent 
towards business tourism or other forms of tourism than those belonging to health domain. Consequently, short stays became as frequent as long stays in terms of average staying in spa resorts. At the same time, a whole range of types of accommodation structures from hotels to boarding houses are available for tourists in these destinations, as nowadays tourists also prefer "out-patient centers located within and outside the centre of town" or "inpatient treatment performed totally or partially in a health centre or in the case of acute illness, in a fully equipped clinic" (ESPA). According to the same organization, no matter the orientation and the specific, a basic condition for the existence of a spa resort is the qualified labor force that may provide "a proper use of naturally occurring local remedies (specific treatment methods) of physical therapies and of prevention and rehabilitation". The adequate equipment for in-patient and out-patient services and wellness programs, which should be offered by a certain number of structures, as well as the hospitality structures and cultural and entertaining programs or even a proper character and appearance of the spa destination in general are also important.

\section{The evolution of spa tourism concept in Romania}

Spa tourism is one of the oldest forms of tourism which raised the interest of people on the European continent since the ancient times. Mineral and thermal springs differing in appearance, taste and temperature from ordinary waters were locally used by the Europeans (e.g. France, Germany, etc.) for their healing powers. Romans had an important contribution in the discovery and the valuing of mineral springs on their territory, gradually extended through military campaigns. It was first during the Roman Empire that tourism was registered as an activity and when spa tourism began to be practiced. Romania, as an ex province of this antique state, founded some of its most famous traditional spa resorts during the Roman period (e.g. Herculane Resort - Hercules Baths; Geoagiu Băi - Germisara).

Another important development stage of the spa resorts began in the $18^{\text {th }}$ century, for those within the Romanian provinces integrated in the Habsburg and later on the Austro-Hungarian Empire and in the early $19^{\text {th }}$ century in the regions located at the East and South of the Romanian Carpathians and continued all along the $19^{\text {th }}$ century and the beginning of the $20^{\text {th }}$ till the First World War. After the $2^{\text {nd }}$ World War, the resorts' infrastructure was modernized, being extended and diversified in a rapid rhythm. In this period, big modern hotel units and sanatorial complexes were built as the demand for health destinations valuing natural therapeutic factors grew. Influenced by the European context, Romania tried to develop a modern health care system, gradually put into place and to value and scientifically fundament, through modern medicine theories and practices, the traditional healing methods. The medical progress, on the one hand, and the morbidity evolution, in which the diseases generated by higher physical and human pressures on human body, due to the modern sedentary and stressing lifestyle had a high share, on the other hand, led to the integration of spa tourism products in the medical and social systems.

Balneal and climate factors have been rediscovered and became part of the health care system, being combined with other pharmaceutical means and even medicines and drug treatments. The interest for natural remedies grew as they became available on a large scale and proved to have long term positive effects with lower costs, while other studies underlined the toxicity and side effects of pharmaceutical products (after Erdeli and Istrate, 1996).

At the same time, a whole ticket system coordinated by Health and Labor Ministries was established. Moreover the role of spas in the social systems is internationally recognized even nowadays at the European level by ESPA which expressed its concern regarding the maintenance of qualitative standards for spa packages at low prices as economic and socio-political conditions suffer radical transformations and face important challenges in different countries. On the other hand, after the $2^{\text {nd }}$ World War tourism industry entered in the mass tourism development stage, orienting towards big hospitality structures, which offered a whole range of modern services. Spa tourism, in particular, responded to human needs of relaxation and health cure during the holiday period, a gaining of the labor force that experienced the era of industrialization and of the social oriented systems and programs governed at the period by different political regimes in different countries all over the Europe.

The Eastern European countries belonging to the communist block enforced even more the social policies reflected into tourism. It is during the communist period, however, when social spa tourism had the most flourishing period in Romania continuing the development of the already settled, traditional mineral and thermal spa destinations and developing ex nihilo a whole range of new resorts. At the end of this period, not less than 160 resorts and localities with therapeutical factors in Romania were known (Erdeli and Gheorghilaş, 1996), an important figure showing the regime's orientation towards the development of this form of tourism and towards 
geological prospections, knowledge and use of the national underground resources.

In the present day, „in a world of non-stop communication, increasing career and family demands, economic uncertainty and escalating demands for time, finding ways to balance our "life load" can be challenging and it is no wonder that the rates of diseases and illnesses are high" (http://www.experienceispa.com). People of modern society have an accelerated rhythm of life compared to the preceding generations and severely feel the effects of industrialization and urbanization. The morbidity became an important indicator as the life expectancy grew and the healthy habits and physical activities reduced or even ceased under the influence of a modern and comfortable life style dominated by mechanization and automatization. The disease number, reflecting the solicitation of human body (degenerative rheumatisms, posttraumatic diseases, cardiovascular, respiratory and metabolic affections) as well as the nutrition diseases grew once people embraced a modern life style. The daily activities stressed human organism, both physically and psychically, through various and complex factors. Consequently, individuals are often in the need to find "a precious refuge from a frenzied space", for which spas could be a solution. Spa concept, as the ISPA defines it, refers to "a time and place to relax and disconnect from the world as you recharge your mind, body and spirit". It represents "the opportunity to bring your physical, mental, emotional and spiritual selves back into alignment. In whatever amount of time you can afford, spas provide peace, relaxation and guidance to help create a healthier lifestyle", being though a solution for a period into which, spa concept, behind tourism industry, became part of our contemporary lives.

Spa lifestyle is a marketing label as sonorous as the eco or the green lifestyle transposing an actual constant element that exists in the life of the present consumer into an already existing but re-polished tourism industry. The changes in the patterns of the consumers' behavior and the modern planning and designing of tourism industry are more pronounced today as compared with the previous time period, generating a rediscovery and use of spa resources. Specialists talk nowadays about a "renaissance" period of spa tourism. More than a solution to cure different diseases, spa is a way to look for oneself. Starting with the previous century, the cosmetic treatments became part of this type of tourism and developed in a real industry in different parts of the world.

Health resorts combined natural remedies and allopath medicine treatments, the latter evolving in parallel with the advances in the medical industry. The last added segment is the medical tourism, part of the health tourism industry next to its spa component (after Dincă, 2006) and in full development nowadays. The complementarily medical procedures and the mix of methods coming both from allopath and naturist medicine determined a redesign of traditional spa destinations into different categories. They appear as different marketing attractions for the modern tourists in search for a holiday which should correspond to their needs, for both a free time from work and a healing time physiologically and/or psychologically. Therefore, spa industry and its representatives through ISPA organization advertises nowadays a whole range of destinations offering personalized and extremely different services "experiences as unique as you are" from hiking and life-style programs to therapeutic massages reaching to laser-facial esthetic surgery and nutritional counseling sessions (http://www.experienceispa.com).

On the other hand, spa packages as health care packages still inherit traditional parts of the medical and labor and social systems determining reactions in this direction. ESPA for instance considered Central and Eastern Europe as an interesting market not only for the traditional development of internal health tourism, as part of the national medical systems and based on the up-raisal of health awareness of citizens in the area, but also for international tourism, as the region is part of the European Union "assuming mutual co-operation within Europe in the fields of health and social welfare" as for instance in terms of a "potential extension of healthcare insurance to cover events abroad".

\section{The classification and distribution of the Romanian spa resorts}

The importance and number of the Romanian spa resorts was strongly influenced along time by the legislation in the tourism field, in general, and in the spa sector in particular and by the development stages of the spa industry, according to their resources (type and volume) and to their maintenance. Due to the old preoccupations for healing natural factors in our country, to prospection activities for mineral resources and interest in their valuing, that reached a climax during the communist period, numerous localities with balneal resources were identified on the whole Romanian territory. According to Urbanproiect, in 1999, 477 settlements with balneal resources were identified in our country. After the 1989 revolution, which marked the fall of the communism regime in Romania, tourism planning considered three categories of resorts in our country no matter of their resources. Spa resorts were consequently divided into three categories, namely: 
tourism resorts of national interest, of local interest and localities with therapeutic factors.

Nowadays, due to more recent changes in legislation and a reevaluation of tourism resources and hospitality structures, only two categories of resorts are recognized, namely resorts of national and of local interest, among which resorts with balneal factors constitute an important number. Therefore, 28 out of the 37 resorts of national interest and 15 out of the 45 resorts of local interest are spa resorts (Figure 1). Their high share within the total number resorts of national interest demonstrates the importance of balneal resources in the development of tourism offer in Romania as in the whole Europe as well "in Europe, mineral springs have long been the focus of health tourism" (Hudson, 2003).

In fact, Romanian tourism, no matter its form of manifestation, still depends to an important extent of natural resources. However, among the spa resorts, several categories may be distinguished and it could be remarked that some destinations do not depend as much on mineral waters, being oriented towards other forms of tourism. Scientists stated in the case of Europe that "in recent times seaside and mountain resorts have also developed with the intention of appealing to the health tourism market" (Hudson, 2003). Usually Romanian mountain and seaside resorts are welcoming more tourists who prefer an active or relaxing holiday in the mountains or sea scenic landscape than a health cure. In the recent years, Romanian mountain resorts oriented through ambitious projects and important investments, especially towards winter sports. In this way, some of the most important mountain destinations became complex resorts.

In Romania, the resorts are classified considering various criteria, one of them considering the natural resources (Figure 1). Another classification of the resorts refers to their location, including: littoral resorts, mountain resorts and balneal resorts. This classification may be considered improper from the point of view of our study, as both mountain and littoral resorts could have and value balneal resorts, displaying the statute of a genuine spa resort. Another classification, focusing more on balneal resources and on spa destinations recognizes: balneal thermal resorts (with mineral waters over $25^{\circ} \mathrm{C}$ ); balneal resorts with mineral waters; marine balneal resorts; balneal resorts with therapeutic peloids and salty waters; resorts for cardiovascular diseases with mineral carbonate waters and mofetes; relaxing resorts located nearby mountain areas and tourism resorts for winter sports and rest. Consequently, within spa resorts two important branches can be distinguished: the first focusing on balneal resources (falling mainly on three categories: mineral springs, sea water and peloids usually related to salty lakes) and the second on climate resources (mainly mountain, pre-mountain and littoral). A general agreed classification, certified by specialized institutions, and quoted in our study, refers to spa resorts of national and local interest, no matter of their location (littoral, mountain, plain or hilly areas), which should contain a national certified and recognized balneal and climate resource no matter its type; health units, equipments and services offered by qualified personnel especially in the balneal field of prevention and rehabilitation, no matter of the treated affection and, not ultimately, proper hospitality structures.

Our study focused on 28 spa destinations, respectively 15 localities considered to be resorts of national interest. The Romanian Master Plan for the Development of Spa Tourism (2009) mentioned these destinations, representing over $90 \%$ of the total spa resorts presented by The Organization of Spa Owners in Romania (OPTBR). Most of them are included in the balneal area considered by the National Institute of Statistics in collecting and processing tourism data on the main tourism areas in Romania.

Geographically, most of the spa resorts of national interest are located in the Carpathians area (Figure 1). Mountains and hilly regions (mainly Subcarpathians) comprise 30 out of the 43 spa resorts certified on the Romanian territory. They concentrate most of the natural balneal resources in our country. If considering the repartition of spa resorts on the development regions, South-East Region has the highest number of health resorts of national interest, mainly due to the seaside resorts cluster (Figure 1). The number of spa resorts, if either their total number or the number of national resorts is considered, is equitable among the 7 development regions (the region of Bucharest is an exception).

Another classification of spa resorts in Romania is based on the treated affections. The specialized institutions divided them into 6 categories, namely:

- spas for rheumatic affections (including the biggest number of spa destinations in Romania located on littoral, plain area, e.g. Lacul Sărat, Amara - Romanian Plain; Băile Felix, Băile Călacea - West Plain) and mainly in the hilly areas due to both salty and sometimes thermal waters);

- spas for cardiovascular affections (located in the Eastern Romanian Carpathians and valuing carbonated mineral springs);

- $\quad$ spas for respiratory affections (based on salines planned for tourists activities - e.g. Govora, Slănic Prahova); 


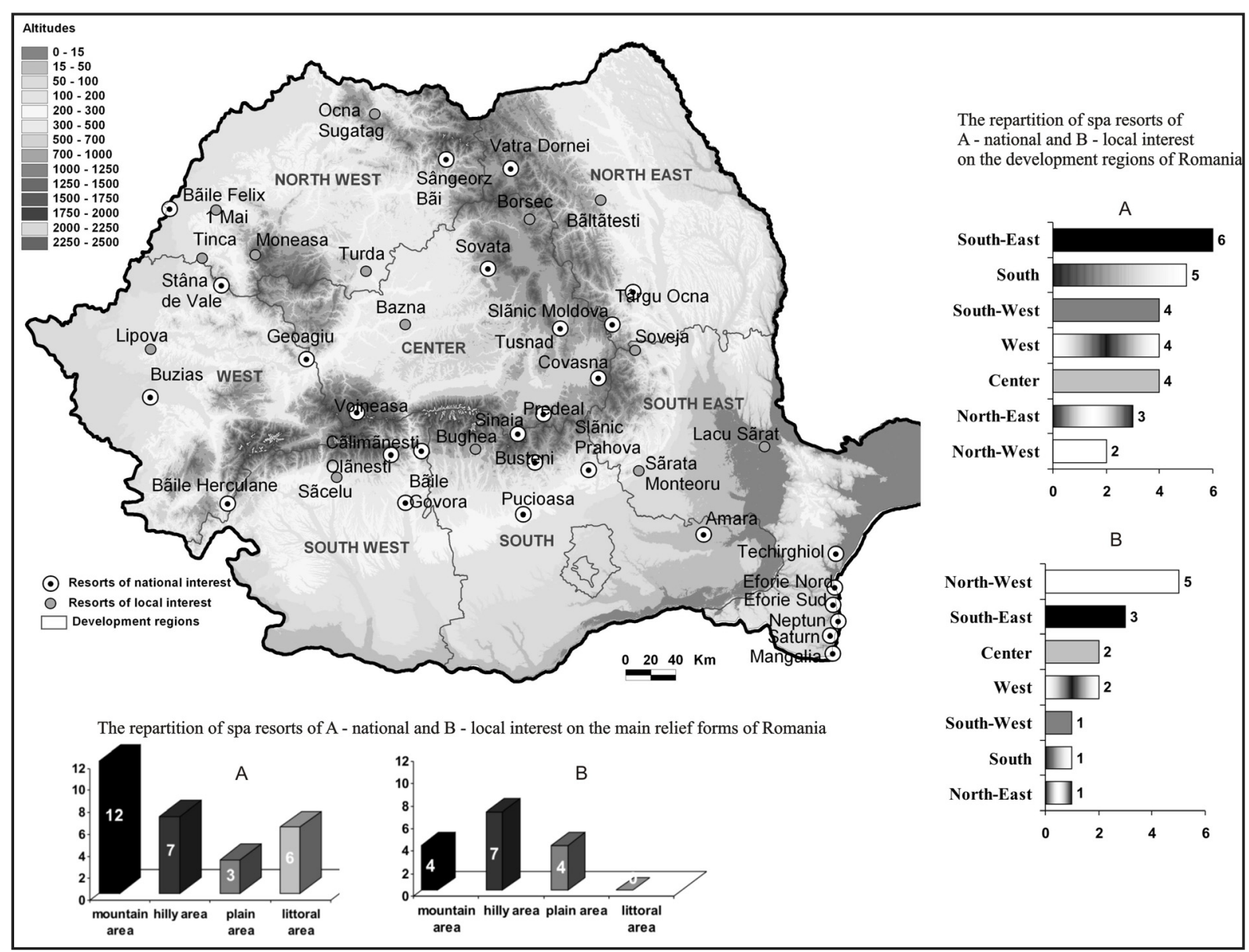

Figure 1. The location of Romanian spa resorts of national and local interest and their repartition on the main relief forms and on development regions (NUTS2).

Source: processed by the authors

- $\quad$ spas for digestive affections and internal diseases (based on mineral springs valued mostly for internal treatment cures e.g. Olănești, Călimănești);

- $\quad$ spas for gynecological affections and

- spas for nervous system affections.

This classification is arguable as many of the resorts have a complex profile, offering treatment for diseases of several categories. Different studies and data basis, evaluating the present offers and endowments of spa resorts in Romania, have been finished in order to develop or promote Romanian tourism offer. OPTBR for instance synthesized, in a more complete table, the therapeutic prescriptions for the Romanian spa resorts (Table 1), giving a more complete image on the offer of the resorts, as beside natural resources different procedures (e.g. baths with curative herbs, electrotherapy, etc.) are also displayed.

The table clearly shows that Romanian spa resorts have a complex offer, diversified over time and oriented towards associated procedures and naturist treatments (apitheraphy (e.g. Băile Herculane, Eforie Nord), acupuncture (e.g. Băile Herculane, Eforie Nord), medical cosmetic treatments (Băile Felix, Băile Herculane, Eforie Nord) (Erdeli, Gheorghilaş, 2006)). Moreover, beside the classical balneal procedures and products, original Romanian treatments and medicines have been introduced (e.g. Gerovital, Boicil, Pell-Amar etc.) (Table 1).

Another important aspect would be the fact that spa resorts developed in time a complex tourism offer orienting towards other less medically foccused and/or more entertaining forms of health tourism and even towards sport and adventure tourism, in the attempt to attract a diversified clientele and among tourists also holiday makers beside cure and treatment seekers. If thermal and salty waters resorts are more oriented towards bathing activities, either in curative or in entertainment purposes, mountain resorts oriented towards both summer and winter active holidays for a different clientele than the usual social spa tourists (Table 2). Almost all spa resorts advertise trekking paths and organize trips in the nearby areas. Cultural theme trips are a frequent option of spa tourists during their long stays, 
especially if located in resorts within or near regions including an interesting cultural heritage like Bucovina, Maramureș, Oltenia etc. On the other hand, spa resorts of national interest modernized, in the recent years, their balneal units and tourism structures and developed interesting sport products aiming to be competitive on international markets.
The Romanian Master Plan for the Development of Spa Tourism (2009) presents a Mac Kinsey matrix showing the strategic positioning on the market for the main Romanian spa resorts, emphasizing that at the moment only Băile Felix/1Mai could be considered an international spa resort, reaching both the qualitative standards for medical and hospitality structures and attracting an important proportion of international demand. Other national spa resorts,

Table 1 The therapeutic prescription of spa resorts of national and local interest in Romania

\begin{tabular}{|c|c|c|c|c|c|c|c|c|c|c|c|c|c|c|c|c|c|c|c|c|c|c|c|c|c|}
\hline & $\mathbf{a}$ & $\mathbf{b}$ & c & d & e & $\mathbf{f}$ & $\mathrm{g}$ & $\mathbf{h}$ & $\bar{i}$ & \begin{tabular}{l|l|}
$\mathbf{j}$ & $\mathbf{k}$ \\
\end{tabular} & 1 & $\mathbf{m}$ & $\mathbf{n}$ & o & \begin{tabular}{|l|l|}
$p$ & $q$ \\
\end{tabular} & $\mathbf{r}$ & $\mathrm{s}$ & \begin{tabular}{l|l}
$\mathbf{s}$ & $\mathbf{t}$ \\
\end{tabular} & $t$ & $\mathbf{u}$ & $\mathbf{v}$ & $\mathbf{w}$ & $\mathbf{x}$ & $\mathbf{y}$ & $\mathbf{z}$ \\
\hline & & & & & & & Trea & atme & ents & & & & & & \multicolumn{11}{|c|}{ Therapeutic recommendations } \\
\hline \multicolumn{26}{|c|}{ National Resorts } \\
\hline Amara & & & & & $\mathrm{x}$ & & $\mathrm{x}$ & $\mathrm{x}$ & & & $\mathrm{x}$ & $\mathrm{x}$ & $\mathrm{x}$ & & & & $\mathrm{x}$ & & & & $\mathrm{x}$ & & & & $\mathrm{x}$ \\
\hline Felix Spa & & & $\mathrm{x}$ & & & & & & & & & & & & $\mathrm{x}$ & & & & & & & & & & \\
\hline $\begin{array}{l}\text { Hercules } \\
\text { Spa }\end{array}$ & & & $\mathrm{x}$ & & & & & & & & & & & & & & & & & & & & & & \\
\hline Olăneşti Spa & & & & & & & & & & & & & & & $\mathrm{x}$ & & & & & & & & & & \\
\hline Buziaş & & & & & & & & & & & & & & & $\mathrm{x}$ & & & & & & & & & & \\
\hline $\begin{array}{l}\text { Călimăneşti } \\
\text { - Căciulata }\end{array}$ & & & $\mathrm{x}$ & & & & & & & & & & & & $\mathrm{x}$ & & & & & & & & & & \\
\hline Covasna & & & & $x$ & & $\mathrm{x}$ & $x$ & $x$ & & $x$ & $x$ & $\mathrm{x}$ & $x$ & & & $x$ & $\mathrm{x}$ & & & & $x$ & $x$ & $\mathrm{x}$ & $x$ & $x$ \\
\hline Eforie Nord & & & & & & & & & & & & $\mathrm{x}$ & & & & & $\mathrm{x}$ & & & & 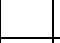 & & & & \\
\hline Geoagiu Băi & & & $\mathrm{x}$ & & & & & & & & & & & & & & $\mathrm{x}$ & & & & $\mathrm{x}$ & & & & \\
\hline Govora & & & & & & & & & & & & . & & & & & $\mathrm{x}$ & & & & \begin{tabular}{l|l}
$x$ \\
\end{tabular} & & & & \\
\hline Mangalia & & & & & & & & & & & & $\mathrm{x}$ & $x$ & & & & $x$ & & & & $\mathrm{x}$ & & & & \\
\hline Moneasa & & & & & & & & & & & & & & & & & & & & & $\mathrm{x}$ & & & & \\
\hline Pucioasa & & & & & & & & $\mathrm{x}$ & & & & $\mathrm{x}$ & $x$ & & $\mathrm{x}$ & & & & & & & & & & \\
\hline $\begin{array}{l}\text { Sângeorz } \\
\text { Băi }\end{array}$ & & & & & & & & $\mathrm{x}$ & & & & & & & $\mathrm{x}$ & & $\mathrm{x}$ & & & & & & & & \\
\hline Saturn & & & & & & & & $x$ & & & & $\mathrm{x}$ & $x$ & & & & $x$ & & & & $\mathrm{x}$ & & & & $\mathrm{x}$ \\
\hline Sinaia & & & & & & & & $x$ & & & & $\mathrm{x}$ & $\mathrm{x}$ & & & & $\mathrm{x}$ & & & & & & & & \\
\hline $\begin{array}{l}\text { Slănic } \\
\text { Moldova }\end{array}$ & & & & & & & & $x$ & & & & & & & $x$ & & $x$ & & & & & & & & \\
\hline $\begin{array}{l}\text { Slănic } \\
\text { Prahova } \\
\end{array}$ & & & & & & & & $x$ & & & & & & & & & $\mathrm{x}$ & & & & $\mathrm{x}$ & & & & $\mathrm{X}$ \\
\hline Sovata & & & $x$ & & & & & $x$ & & & & $\mathrm{x}$ & & & & & $x$ & & & & $\mathrm{x}$ & & & & $x$ \\
\hline $\begin{array}{l}\text { Vatra } \\
\text { Dornei } \\
\end{array}$ & & & & $\mathrm{x}$ & & & $x$ & $x$ & & & $\mathrm{x}$ & & & & & & $\mathrm{x}$ & & & & $\mathrm{x}$ & & & & $x$ \\
\hline \multicolumn{26}{|c|}{ Local resorts } \\
\hline $\begin{array}{l}\text { Băile Felix - } \\
1 \text { Mai }\end{array}$ & & & $x$ & & & & & & & & $\mathrm{x}$ & $\mathrm{x}$ & & & & & & & & & & & & & \\
\hline Călacea Spa & & & & & & & $\mathrm{x}$ & & & & $\mathrm{x}$ & $x$ & & & & & & & & & & & & & \\
\hline Lacul Sărat & & & & & & & & & & & & & & & & & & & & & $\mathrm{x}$ & & & & \\
\hline Oglinzi & & & & & & & & & & & & $\mathrm{x}$ & $x$ & & & & $x$ & & & & & & & & \\
\hline Turda & & & & & $\mathrm{x}$ & & & $\mathrm{x}$ & & & $\mathrm{x}$ & $\mathrm{x}$ & & & & & $\mathrm{x}$ & & & & $\mathrm{x}$ & & & & $x$ \\
\hline \multicolumn{26}{|c|}{ Localities with therapeutic factors } \\
\hline $\begin{array}{l}\text { Ocna } \\
\text { Sibiului } \\
\end{array}$ & & & $\mathrm{x}$ & & & & & & & & & $\mathrm{x}$ & & & & & & & & & $\mathrm{x}$ & & & & \\
\hline Praid & & & & & & & & $\mathrm{x}$ & & & & & $\mathrm{x}$ & & & & $\mathrm{x}$ & & & & & & & & \\
\hline Vața de Jos & $\mathrm{x}$ & & $\mathrm{x}$ & $\mathrm{x}$ & $\mathrm{x}$ & & $\mathrm{x}$ & $\mathrm{x}$ & $\mathrm{x}$ & & & $\mathrm{x}$ & & $\mathrm{x}$ & & $x$ & $\mathrm{x}$ & & $\mathrm{x}$ & & & & $\mathrm{x}$ & $\mathrm{x}$ & $x$ \\
\hline
\end{tabular}


Table 2 Leisure infrastructure existing in the main spa resorts in Romania

\begin{tabular}{|c|c|c|c|c|c|c|c|c|c|c|c|c|c|c|c|c|c|c|c|c|c|c|c|}
\hline & $\mathbf{a}$ & b & c & d & e & $\mathrm{f}$ & g & h & i & $\mathbf{j}$ & $\mathbf{k}$ & 1 & $\mathrm{~m}$ & $n$ & $\mathbf{o}$ & p & $q$ & $\mathbf{r}$ & $\mathbf{s}$ & $t$ & $\mathbf{u}$ & $\mathbf{v}$ & w \\
\hline Băile Felix & $x$ & $x$ & $x$ & $x$ & - & $x$ & $x$ & - & - & - & $x$ & - & - & $x$ & $x$ & $x$ & - & $x$ & $\mathrm{x}$ & $x$ & - & - & - \\
\hline Felix - 1 Mai Spa & - & $x$ & $x$ & $\mathrm{x}$ & $x$ & - & - & - & $x$ & - & - & - & - & - & - & - & - & - & - & $x$ & - & - & - \\
\hline Vatra Dornei & $x$ & - & $x$ & - & $x$ & $x$ & $x$ & $x$ & $x$ & $x$ & $x$ & $x$ & $x$ & $x$ & $x$ & $x$ & $x$ & $x$ & - & $\mathrm{x}$ & $x$ & $x$ & - \\
\hline Herculane & $\mathrm{x}$ & $x$ & $x$ & $x$ & $x$ & $x$ & $x$ & - & $x$ & $x$ & $x$ & - & - & $x$ & - & $x$ & - & - & - & - & - & - & - \\
\hline Govora & - & - & $x$ & - & $\mathrm{x}$ & $x$ & $x$ & - & - & $x$ & $x$ & - & - & $\mathrm{x}$ & $x$ & $x$ & - & - & - & - & - & - & - \\
\hline Sângeorz - Băi & $x$ & - & - & - & $\mathrm{x}$ & $x$ & $x$ & - & - & - & $x$ & - & $x$ & $\mathrm{x}$ & - & $x$ & - & $x$ & - & - & - & - & - \\
\hline Băile Olăneşti & $\mathrm{x}$ & - & - & - & $\mathrm{x}$ & $x$ & $x$ & - & - & $\mathrm{x}$ & $x$ & - & - & - & - & $x$ & - & - & - & - & - & - & - \\
\hline Călimăneşti - Căciulata & $\mathrm{x}$ & $x$ & $x$ & $x$ & $\mathrm{x}$ & $\mathrm{x}$ & $\mathrm{x}$ & - & $\mathrm{x}$ & - & $\mathrm{x}$ & $x$ & $x$ & $\mathrm{x}$ & $\mathrm{x}$ & $x$ & - & $x$ & - & - & - & - & - \\
\hline Băile Tuşnad & $\mathrm{x}$ & $x$ & $x$ & $\mathrm{x}$ & $\mathrm{x}$ & $x$ & $\mathrm{x}$ & $\mathrm{x}$ & $\mathrm{x}$ & - & $\mathrm{x}$ & - & - & $\mathrm{x}$ & $x$ & $x$ & - & $x$ & - & - & $x$ & $\mathrm{x}$ & $\mathrm{x}$ \\
\hline Covasna & $\mathrm{x}$ & $x$ & $x$ & - & - & $x$ & $x$ & $x$ & - & $x$ & $x$ & - & - & - & - & $x$ & - & - & - & - & - & $x$ & - \\
\hline Slănic Moldova & $x$ & - & - & - & $x$ & $x$ & $x$ & - & - & - & $x$ & - & - & $x$ & $x$ & $x$ & - & $x$ & - & - & - & - & - \\
\hline Sovata & $x$ & $x$ & $x$ & $x$ & $x$ & $x$ & $x$ & - & - & $x$ & $x$ & - & $x$ & $x$ & $x$ & $x$ & - & - & - & - & - & $x$ & - \\
\hline
\end{tabular}

a - covered pool; b - open air pool; $\mathrm{c}$ - thermal water pool; $\mathrm{d}$ - bathing basin; e - polyvalent sport area; $\mathrm{f}$ - disco club; $\mathrm{g}$ organizing trips; $\mathrm{h}$ - mountain bike rent; $\mathrm{i}$ - hiking; $\mathrm{j}$ - concert hall/cultural house; $\mathrm{k}$ - cinema; $\mathrm{l}$ - handball terrain; $\mathrm{m}$ volleyball terrain; $\mathrm{n}$ - tennis terrain; o - football terrain; $\mathrm{p}$ - trekking; $\mathrm{q}$ - river rafting; $\mathrm{r}$ - fish breeding basins; $\mathrm{s}$ - flight shooting; $\mathrm{t}$ - horse riding; $\mathrm{u}$ - paint ball; $\mathrm{v}$ - winter sports (ski); $\mathrm{w}$ - nautical sports.

Source: after INCDT / NIRDT, 2006 (National Institute of Research and Development in Tourism)

such as Vatra Dornei, Slănic Moldova and to a less extent, Băile Herculane aspire to this statute, trying to attract incoming tourists. On their turn, Covasna and especially Sovata already attract international tourists in search for medical tourism, but need significant investments in the infrastructure in order to raise their standards and to diversify their offer, so as to reach an international statute. Another important group of resorts, i.e. Amara, Sângeorz Băi, Băile Olănești, Călimănești and Băile Govora, belongs to the social balneal segment and try to raise their standards by orienting more towards entertainment and internal demand, in the attempt to consolidate their statute as resorts of national interest. Mangalia comes from the social spa tourism sphere but displays better qualitative standards for both medical and tourism services and strategically intend to strengthen both medical and leisure segments aspiring an international statute.

\section{Romanian spa tourism industry - communist heritages in the post communist era}

Similarly to other countries in Central and Eastern Europe, spa tourism represents an old phenomenon in Romania which expanded to the dimensions of a well defined tourism industry during the mass tourism period, which corresponded to the communism epoch. Many of the resorts were entirely build in this period and, in parallel, the already existing older resorts added important volumes in terms of hospitality structures. All medical structures were modernized, adding new equipments and procedures. On the other hand, various studies investigated the effects of the natural factors in spa resorts, leading to the certification and accredited exploitation of already recognized springs or of new sources and even to researches and elaboration of new pharmaceutical products. The progress in medicine led to the scientific fundament of the traditional methods, empirically used in the past. Some of them were brevetted as spa and/or cosmetic products of Romanian origin. Consequently, two decades after the 1989 revolution and the fall of the communism regime spa resorts still preserve important elements from that period. They can be labeled as "communist heritage" in the post communist period as resorts' transition was a difficult process, for some of them not finished yet. Moreover, inherited communist elements represent a landmark for Romanian spa tourism. The most pregnant and important through the economic and landscape effects they generated are the large spa structures displaying large hospitality structures and the medical clinics/centers, while from the immaterial point of view, the social character of spa tourism and its low economic efficiency and international competitiveness could be remarked.

\section{Mass hospitality structures a characteristic of Romanian spa resorts}

The specific infrastructure of spa resorts refers to accommodation structures including medical treatment structures. Hotels offering spa and medical facilities could hardly be found elsewhere, as spa resorts concentrate over $80 \%$ of their number (Figure 2 b). This specific infrastructure developed as a result of massive expansion and modernization of spa resorts which took place after the $2^{\text {nd }}$ World War, when a significant number of hotel and sanatoria units was built, offering over 30000 bed places of a superior comfort (Erdeli and Gheorghilaș, 2006). 

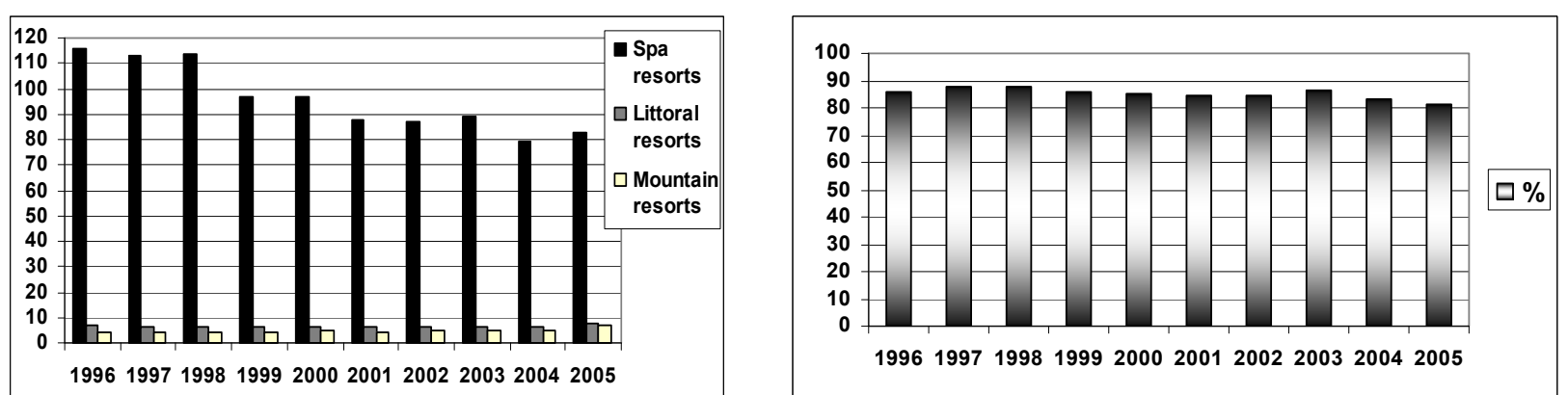

Figure 2. a - Accommodation structures including medical treatment structures on types of tourism destinations (absolute figures); $\mathrm{b}$ - Ponder of the number of accommodation structures including medical treatment structures in spa resorts in total number of accommodation structures including medical treatment structures (relative figures).

Source: Processed data from the National Institute of Statistics

Resorts displaying thousands of bed places and containing large hotel and sanatoria units appeared, offering not only accommodation, but also catering and medical services (e.g. Băile Felix, Băile Herculane, Sovata, Băile Tuşnad, Covasna, Căciulata, Călimăneşti, Amara, Sângeorz-Băi, Mangalia, SlănicMoldova, Vatra Dornei, Eforie Nord, etc). Consequently the share of bed places in the accommodation structures including medical treatment structures in the total number of bed places in accommodation structures at the level of spa resorts (over $50 \%$ and reaching over $60 \%$ in 2002) (Figure $3 \mathrm{~b}$ ) is higher than the share at the level of the number of units (22\% up to $25 \%$ ) (Figure 3a).

These figures underline that massive accommodation structures and big spa facilities are dominating spa resorts' tourism offer, being among the most important national tourism stakeholders in the sector.

After the '9os, the number of these structures decreased (Figure 2 a) due to the important political, social and economic changes occurring in the Romanian society which passed from a centralized and state owned economy to the market economy, inevitably affecting the tourism sector. The large balneal complexes or medical villas were among the state owned properties passing through one of the

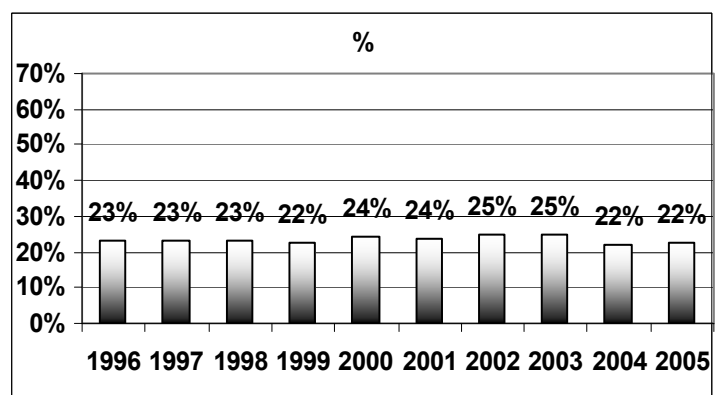

longest processes of privatization in the tourism sector. The unclear property statute for many of these accommodation units and their exploitation on a social system basis without major investments from the part of different temporary administrators, led to the degradation and temporary or final closing of many of them. In 1996, the total number of the accommodation units including medical treatment structures in the spa resorts reached 116, while in 2005 their number decreased to 83 units (Figure 2 a). Beside the decrease in the unit and bedplace's number (felt more acute after 2002 - Figure 3 b), a severe decline in the indicators of economic efficiency and important environmental consequences should be considered. The large and tall communist structures (Figure 3 ) are a pregnant landmark as they dominate the landscape and contribute to a large extent to the overall tourist's perception on the tourism destination. Their maintenance is consequently an imperative condition in order to keep resorts' aesthetic and should be a priority for the integrative sustainable destination planning strategies. The evolution in the bed places' number by comfort category suggestively shows a major decrease of the superior comfort bedplaces $(4$ and 5 stars and especially of 3 stars). The decrease of approximately $90 \%$ for bed places ranked at 3 stars

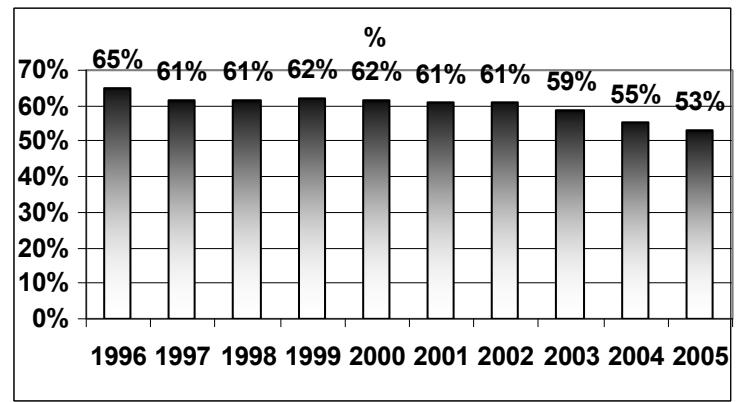

Figure 3. a - Ponder of the number of accommodation structures including medical treatment structures in the total number of accommodation structures at the level of spa resorts; $b$ - Ponder of the number of the bedplaces in accommodation structures including medical treatment structures in the total number of bedplaces in accommodation structures at the level of spa resorts.

Source: Processed data from the National Institute of Statistics. 
category, in the Romanian spa resorts, in 2005 compared to the base level in 1989 is compensated by an important increase of the 2 stars and even 1 star categories and shows an obvious decline of these structures, explained, as already mentioned above, by the lack of investments and the expensive maintenance of these structures which continued to depend on social tourism.

The economic recession and generally the last socio-economic transformations led not only to a gradually smaller governmental support for this type of tourism, but also to a smaller capacity and willingness of public and private stakeholders to administer and invest in these units as a profitable economic activity. The lack of investments and improvement of the tourism facilities andthe poor promotion and support of the governmental authorities induced a decrease of the tourist's interest for this type of tourism, the visitors preferring other more attractive forms of spa tourism advertising modern accommodation units and complex wellness services. The high proportion of Romanian outgoing tourism and domestic tourist's preference for abroad spa destinations put pressure on the long-run competitiveness of the resorts. All these factors emphasize the decrease of the accommodation capacity, both considering the units number and bedplaces number, in 2010 compared to the 1989 base level. A slight recovery in the number of accommodation units, of approximately 40 units, representing nearly 5\%, was registered between 2005 and 2010 compared to the basic level registered in 1989 due to small capacity boarding houses and hotel units built after the revolution, but not necessarily for spa tourism.

\section{Romanian spa tourism a market still dominated by social tourism}

In spite of the new trend displayed by spa tourism through its orientations towards wellness, cosmetic and fitness services, which attracts in terms of travel budget especially wealthy people, it still attracts and, at the same time, depends on the social tourism market. Spa tourism, traditionally referred and developed during the communism epoch with the state support and oriented through its health central system, towards older people, offering cure for different affections or through trade unions towards workers in search for a relaxing spa holiday.

The recent period found in place and continued to support the existing social holiday system through new institutions. "The National Pension and Other Social Insurance Funds play a critical role in supporting social tourism through the system of subsidized or free spa treatment vouchers for retired persons or disabled adults" (Calypso Study on Social
Tourism - Romania, 2010). Each year, the National Pension Funds and CNPAS (The National House of Pensions and Other Social Insurance Rights) as the institution "in charge of the management of the national pension fund and of the social insurance fund for people suffering from work accidents and occupational diseases" implements a special Spa Social Tourism Program for retired and disabled people during which it "distributes 'free vouchers' for retired people who suffer from a disability and 'subsidized vouchers' for retired people".

Another institution involved in this process is of course the OPTBR which includes 60 members from the most important Romanian spa resorts and promotes Romanian spa tourism at both national and international level. As a member of ESPA and patronate organization, the OPTBR leads lobby actions to protect and represent the interests of its members.

The government authorities created two offseason tourism programs namely: "The spa decade" and "A week of recovery in a Spa" organized and promoted yearly by OPTBR, next to other major offseason national tourism programs designed for Romanian seaside, mountain and countryside destinations. These programmes were developed in order to extend the tourism season and to support the long term economic profitability of tourism businesses, and the revival of internal tourism on social principles. However both public and private stakeholders expressed their wish to get involved in European social tourism development as the Romanian spa tourism market depends to a great extent on the internal demand. The economic agents are attracted by the state supportive grant ticket system and prefer mainly spa treatment tickets and to a less extent rest vouchers. The number of distributed vouchers is set according to the yearly CNPAS budget and tickets could be used by the beneficiaries in CNPAS own spa locations managed by the "TBRCM" SA, the public company for spa treatment and recovery of work ability or in private spa locations that have a contract with the CNPAS (after Calypso Study on Social Tourism - Romania, 2010).

After the political transformations in 1989 the ticket system was transferred to the habilitated newly formed institutions and ministries. The number of distributed spa treatment tickets grew after 1992, overpassing the value of 200000 in 1995 and of 300000 in the period $2001-2003$ (Figure 4). Due to financial difficulties and to the limitation of expenses in the social sector, the number of tickets decreased after 2003, reaching a value of $\mathbf{2 4 1 2 5 2}$ vouchers in 2008 and of 217231 vouchers in 2009. In 2010, due to the economic recession and the budgetary expenses problems faced by the government, on the one hand, but also to the changes in the regulations regarding 

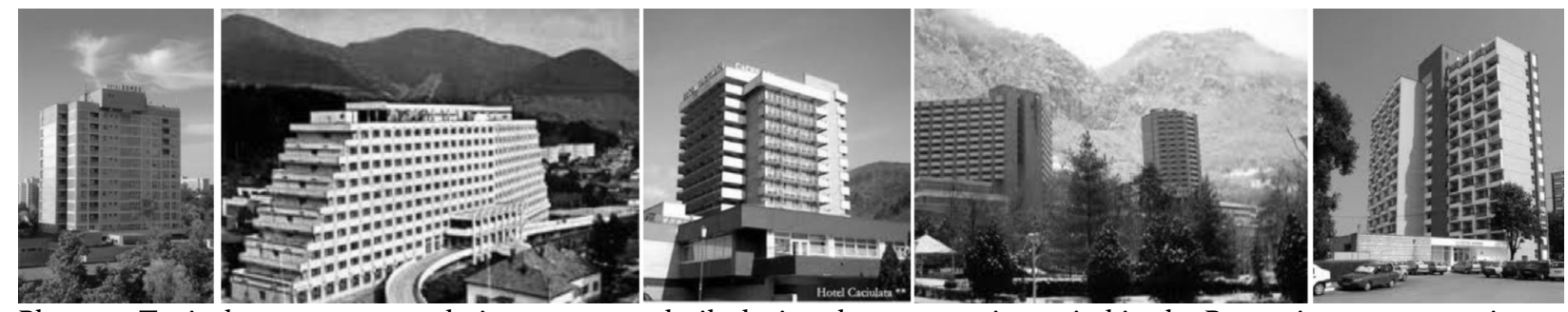

Photos 1. Typical mass accommodation structures built during the communist period in the Romanian spa resorts in a Hotel Someș - Băile Felix resort ; b - Hebe Hotel - Sângeorz Băi resort; c - Hotel Căciulata - Călimănești - Căciulata resortş d - view upon Herculane resort; e - Sirena Hotel - Saturn resort Source: internet

the spa treatment vouchers, on the other hand, the program was interrupted for several months.

If considering the evolution of the yearly number of spa treatment tickets granted by the state insurance system on the main spa resorts in Romania after 1992 (Figure 5) the resorts with the highest number of tickets (over 25000 per year in 2005 each of them) are Băile Felix and Băile Herculane. On a second level, Băile Olănești, Călimănești-Căciulata and Covasna resorts distributed around 20000 spa treatment vouchers in 2005. Other important resorts could be considered Amara (over 11000 tickets in 2005), Govora, Sângeorz Băi and Saturn (each of them receiving 9000 tickets in 2005), Vatra Dornei and Eforie Nord (over 8000 each in 2005), Mangalia, Sovata, Tuşnad, Buziaş, Lacul Sărat (over 7000 each of them in 2005).

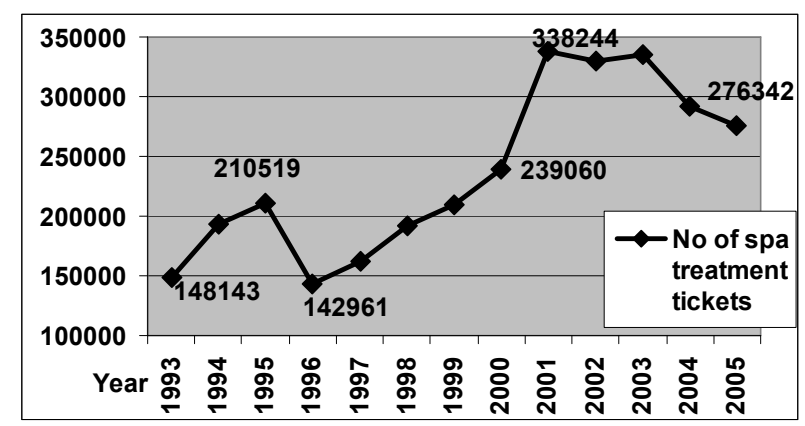

Figure 4. The yearly number of spa treatment tickets granted by state insurance system

Source: The Ministry of Labour, Family and Social Protection

Only some of the resorts registered a continuous rising number of tickets between 1993 - 2005. For instance, Băile Felix, Băile Herculane registered both an uprising as the first resort was distributed 12255 tickets and the second 13624 tickets in 1993. Căciulata, Olănești and Covasna registered important and continuous risings, while Amara and Sângeorz Băi; 1 Mai and Lacul Sărat registered the most important positive differences between 2000 and 2005 of over 4000 and 3500 tickets, respectively. Bălţătești had an interesting evolution being distributed spa treatment vouchers since 1999 (over 1300 tickets) and growing continuously to over 4000 tickets in 2005. Vatra Dornei had one of the most constant evolutions, if the three reference year levels are compared. However, the resort registered and important decrease in 2005 of about 12000 tickets in the period $2002-2003$. Sovata had also a much bigger number of over 10000 tickets in 2001 than in 2005. For both Sovata and Vatra Dornei the diminishing in the number of spa treatment vouchers offered through the social insurance system was also generated by higher standards and, at the same time, by higher prices imposed on the market by the modernization of accommodation units and treatment basis as the ministry signed contracts with competitors, offering the same services at lower prices.

Other important decreases were registered by Târgu Ocna resort, from a very low level of 548 vouchers in 1993 to a peak of over 7000 vouchers in 2001, followed by a decrease in 2005 when receiving only 2375 vouchers. Eforie Nord resort had, by far, the most important decrease from over 20000 vouchers in 2000 (over 26000 in 2001) to 8581 in 2005 (Figure 5). Compared to the number of spa treatment vouchers, only a small number of rest vouchers were granted. About 45000 - 50000 tickets were distributed each year during 2003 - 2006 period.

However, the increasing number of retired persons and the financial difficulties met by the Government, in the late period, led to the insufficiency of the spa treatment vouchers compared to the higher number of demands. The subsidized treatment vouchers in spa resorts is the main support system for retired people, providing the typical tourists met in the spa and medical facilities of the above mentioned and cartographically represented destinations. According to the Calypso study (2010), the holiday spa treatment voucher became a tradition of the Romanian social tourism, representing the only option of holiday for the majority of retired people. "At least $80 \%$ of the treatment vouchers, available every year through CNPAS, are distributed to retired people". Therefore, the visitor profile for Romanian spa resorts is mainly characterized by old retired people, who can benefit from granted or free vouchers for a spa holiday, choosing for a 18 days stay package, including full board accommodation and two spa treatments per day. 
According to the regulations established by The Ministry of Labour, Family and Social Protection and CNPAS, the cost of a holiday is: $70 \%$ of their monthly pension in peak-season period (between 15 May and 31 August) and 50\% of their monthly pension in offseason period (rest of the year). The estimation of the Calypso study on social tourism in Romania (2010) indicated that "during the Spa holiday, $50 \%$ of the retired people spend less than 100 euro for extra expenses during their 18-day stay". Consequently, the high number of old socially supported tourists in the Romanian spa resorts could be explained, on the one hand, by the increasing number of retired people, due to an accelerate ageing, and on the other hand, by people's small revenues and financial impossibility to choose for non-socially supported forms of tourism.

Even so, a significant number of aged people in Romania do not practice tourism at all, and even for the contingent of participants, a subsidized holiday imposes substantial financial efforts as their very lowincome do not allow the seniors to satisfy their essential needs. Another reason is the lack of free time, as retired people in rural area are mostly involved in subsistence agriculture, while those living in the urban areas are babysitting their grandchildren and take care of housework (after Calypso Study on Social Tourism - Romania, 2010). However, spa and medical tourism are the first to correspond to the needs of old people in search for both relaxation in a nice environment and professional medical care. Moreover, balneal tourism used to be a traditional social form of holiday and is perceived to be nowadays among the cheapest in Romania.

According to the National Institute of Statistic, the population aged 65 and above counted over 3,200,000 persons in 2010, compared to approximately 3,000,000 in 2000 and only $2,383,435$ in 1990. The statistics revealed that in November 2009, the number retired people living on social insurance funds was over 4,750,0oo, with an average monthly income of 180 euro and approximately 776,700 retired peasants living on social insurance funds, with an average monthly income of 75 euro (Calypso Study on Social Tourism - Romania, 2010). The social tourism strategy (2010) estimated that, in the first quarter of 2009, there were 348,975 retired tourists, $50 \%$ of which being aged of 65 and over. The length of stay of a third of them was at least 4 overnight stays which may correspond to a spa tourism motivation. This presumption may be

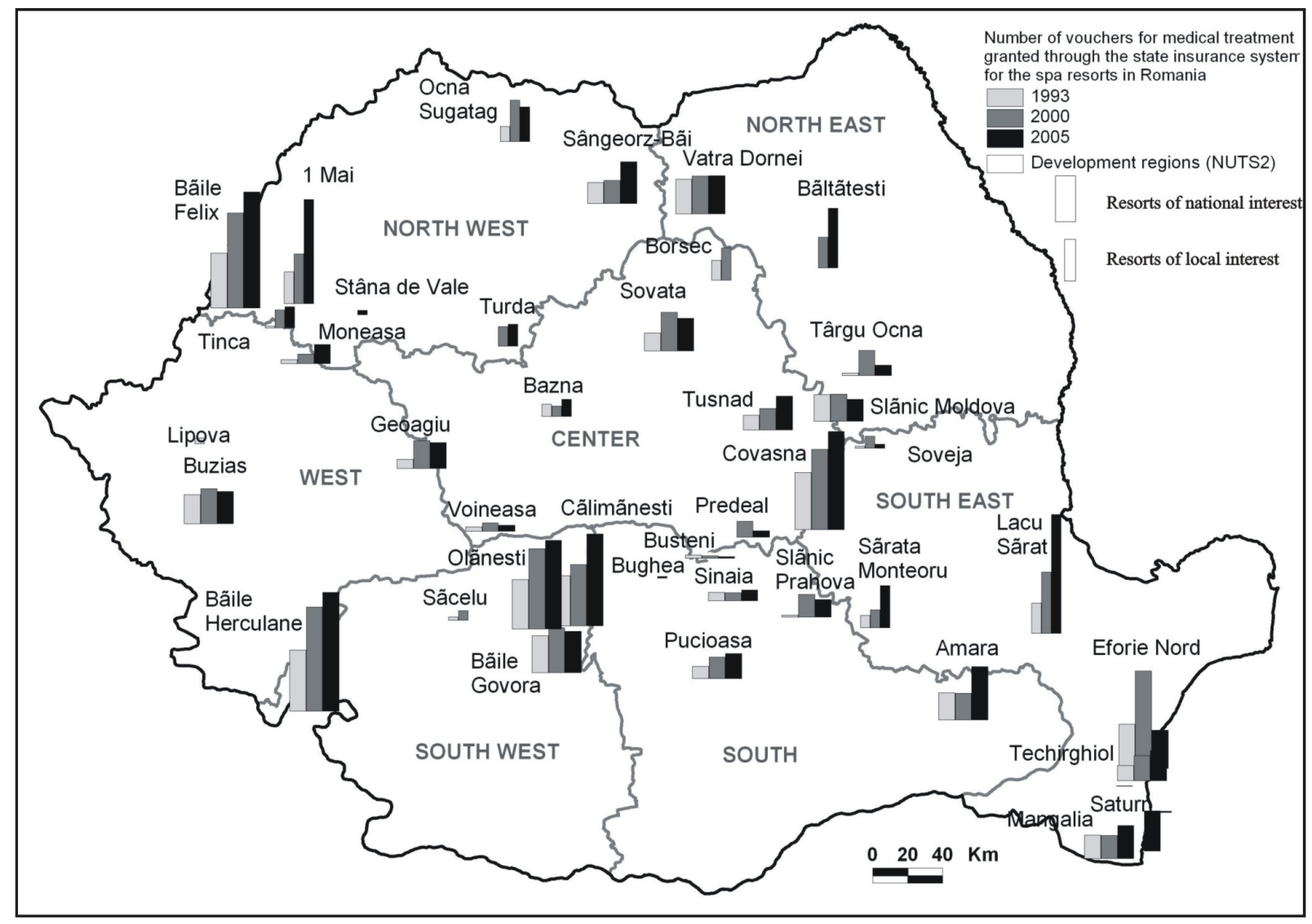

Figure 5 . The evolution of the yearly number of spa treatment vouchers granted by the state insurance system on the main spa resorts in Romania between 1993 and 2005.

Source: The Ministry of Labour, Family and Social Protection 
supported by the higher share of those preferring a longer period of stay and who were aged 65 years and over. The strategy also estimates, based on the analysis of different statistical figures and open interviews that " $70 \%$ of spa tourists are 50 years old and above and that $80 \%$ of them go for spa treatment".

The figures provided by the National Institute of Statistics for spa resorts emphasize that, during 1989 - 2005 period, the demand for this type of destination decreased by over $60 \%$. In terms of tourists' origins, Romanian tourists are responsible for a diminution in the arrivals from 1692053 tourists in 1989 to 613654 tourists in 2005 mainly because social tourism was less supported by the state through pension fund and by privatized companies. At the same time, the purchasing power and the welfare of the population decreased after 1989, the budget for travelling and holidays for the large mass of population being significantly decreased. Consequently, spa tourism was severely affected. Moreover, foreign destinations became more interesting for the residents and a better option, both in terms of quality and tourism services especially for young and adult tourists. Therefore, the all year round long stays in spa resorts were replaced mostly by summer shorter stays, even in the case of tourists motivated by spa tourism. As for incoming tourism, it increased with approximately $8 \%$ for Romanian spa tourism destinations over the 1989-2005 period. However, foreign demand oriented towards famous Romanian destinations and seemed motivated mainly by other forms of tourism than the classical spa treatments, generating a decrease in the average stay from 8.7 days in 1989 to 4.1 days in 2005 . The average stays in hotels decreased even to a greater extent from 12.9 days in 1989 to 4.3 days in 2005 . The average stay in spa resorts of the Romanian tourists are almost the same or slightly different in the case of the hotel stays, decreasing from 10 days in 1989 to 9.2 in 2005 , underlining that the domestic residents remained almost entirely oriented towards the classical spa tourism.

At the same time, incoming mass tourism decreased as other strong competitive foreign destinations (e.g. Bulgaria, Turkey) offered modern and sunny destinations at better prices displaying obvious advantages especially compared to the Romanian seaside resorts. Medical spa resorts became less attractive for the incoming spa tourism, lowering their comfort and qualitative standards as they entered a difficult privatization process lacking investments and a solid marketing oriented long term development strategy. The small increase of foreign tourism demand appears in this context more like a result of the adaptation, diversification and embracement of new forms of tourism, in case of the tourism industry in the Romanian spa resorts still laying on considerable balneal and climate resources and displaying important elements of the communist epoch.

\section{The efficiency of the Romanian spa tourism}

The profound socio-economic transformations occurred in the last two decades of transition to the market economy determined important socioeconomic changes in the tourism spa resorts. The difficult process of privatization, due to the great value of shares and important investments needed by the big hospitality structures in spa tourism industry and to the slow ownership restitution process caused important losses for this sector and generally made difficult its restructuration and modernization. The decrease in the number of arrivals and overnight stays lowered the occupancy rate from $73.2 \%$ in 1989 to $49.5 \%$ in 2005 affecting to a lower extend the hotel units, for which the occupancy rate decreased from $84.9 \%$ to $64.9 \%$.

The decrease in the use level of accommodation capacity in function affected the long term economic efficiency of the industry. The diminishing of accommodation capacity in function and of occupancy rate and the physical changes determined by the lack of modernization of buildings belonging both to hospitality and to treatment structures and of medical equipments, determined an important restructuration of the specialized labor force. The volume of workforce in tourism and of specialized employees in medical tourism gradually diminished. The latter, as a specialized type of labor force in the sector, was reduced, both through external factors (decrease of tourism demand) as well as through internal ones (i.e. the lack of attractiveness of the sector for new employees and/or the reorientation of the already employed qualified personnel towards more profitable medical units and destinations). In view of future plans of reviving end developing this tourism sector, for which Romania has important resources, the trained labor force is a key issue to be focused on. The labor force in hospitality suffered as well important changes as the seasonality, affecting also balneal resorts, determined major lay-offs in the sector and abroad emigrations of the qualified labor force or the increase of the temporary non-qualified labor force. The last variable was also determined by major lay-offs in other unproductive economic sectors and the temporary orientation of a part of the unemployment in search for a source of income, towards jobs, even if low paid, in the tourism sector. The number of employees and its evolution is consequently one of the most important variables of tourism in general and of spa tourism in special as it determines the productivity of the sector, the 
quantity, diversification and quality of services and, ultimately, its economic profitability and efficiency.

Between 2000 and 2004, the number of employees in Romanian spa tourism destinations shows a positive difference for the large majority of the resorts (Figure 6). Therefore, this indicates a revival of the tourism sector, but not necessarily in terms of spa tourism. The significant fluctuations from one year to another emphasize a high instability of the industry depending mainly on investor and owner's power and determination to develop a long term business.

A much debated case is the one of Băile Herculane resort, which shows one of the most important positive changes in terms of labour force in tourism in the analyzed period, but in the case of which spa tourism, that made famous the resort in the past, needs major investments. However, in the last years, the resort stirred important administrative efforts for its revival. Successful examples for the spa industry proved to be Băile Felix and Sovata resorts where the labour force in tourism increased with more than 150 employees and obviously Eforie Nord which registered an increase of over 500 employees for the same 2000 - 2004 period. However the last mention resort registered also important decreases in this period compared with the first two mentioned resorts which registered only small fluctuations. Continuous or small fluctuating important increases of tourism employees were registered by Târgu Ocna, SângeorzBăi and Călimănești - Căciulata - Cozia resorts mainly due to revival of spa tourism, but also to the development of other forms of recreational activities. Vatra Dornei and Borşa are resorts which increased considerably the employment in the sector over the same above mentioned period, developing mainly active mountain tourism and leisure recreational activities and secondarily spa services. Significant decrease in the tourism labour force were registered in Mangalia (over 400 employees) and also in Băile Olănești, Borsec and Geoagiu Băi which suffered important restructurations affecting severely tourism employment and jeopardizing the future of the industry.

\section{Existing strategies, recommendations for the future development of the spa tourism}

In the last few years, the continuously restructured Ministry of Tourism, newly denominated the Ministry of Regional Development and Tourism, took important actions with regard of designing and implementing expert accredited sustainable tourism

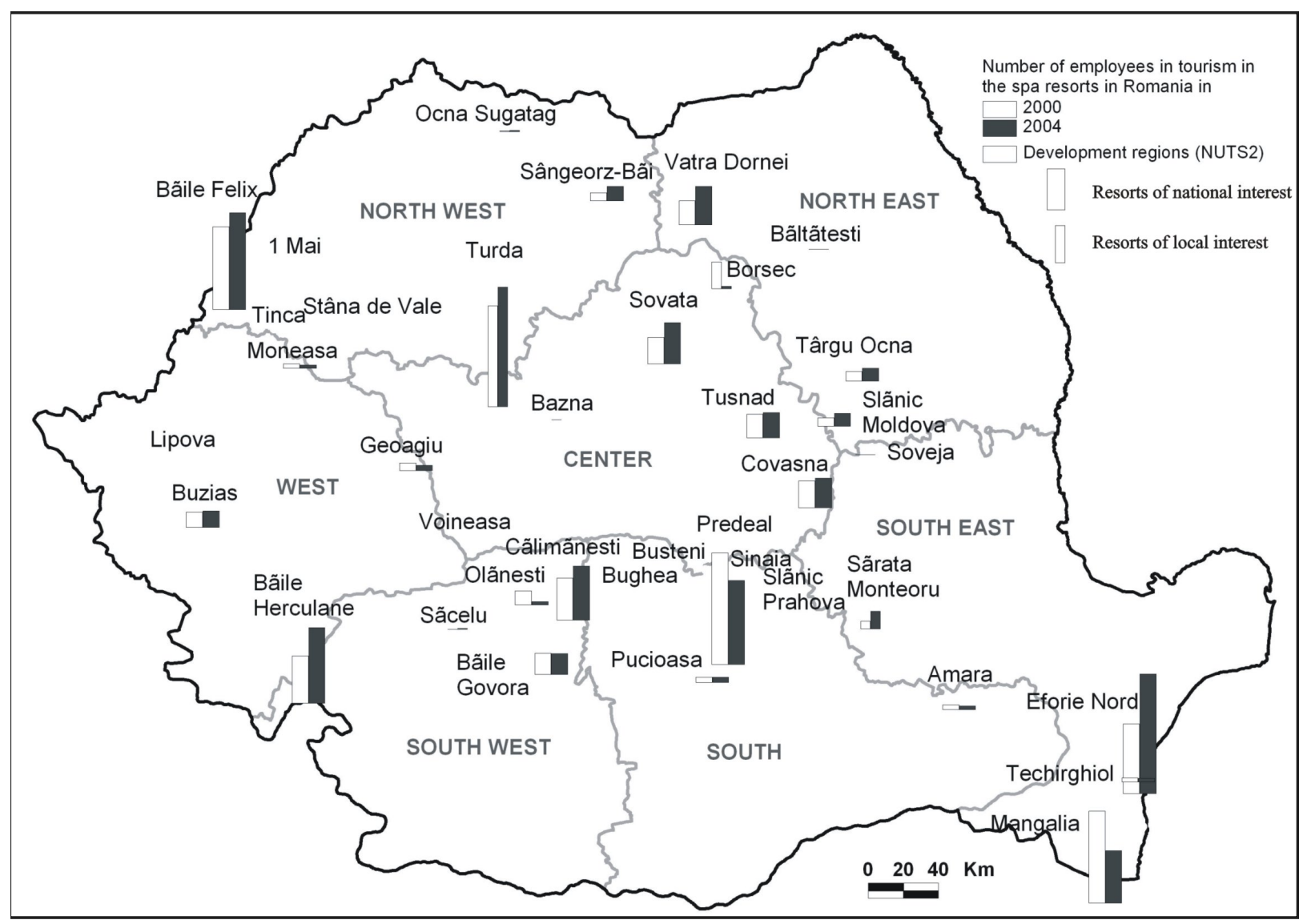

Figure 6. The evolution of the number of employees in tourism sector in the spa resorts in Romania between 2000 and 2004.

Source: The National Institute of Statistics. 
strategies for tourism, in general and different tourism sectors, in particular, meant to help the revitalization and planning in a new modern shape of the industry. After a long period of decline and stagnation due to the inertia of social system structures, traditionally dominating Romanian spa tourism sector, the difficult and slow privatization process of the balneal hospitality industry and on the influence of the worldwide increasing markets of spa consumerism and health care tourism, spa tourism was inevitably reconsidered by the Romanian authorities as a priority area. Consequently, both global tourism strategies and sector oriented strategies focused this tourism sector.

Continuing the initiative materialized in 2006 through the Strategy for Spa Tourism elaborated by INCDT for the National Authority in Tourism - ANT, the Ministry of Regional Development and Tourism launched in November 2009 the Master Plan for Spa Tourism Development second phase and its Action Plan both elaborated by Détente Consultants. The same group of experts finalized in 2010 a country report on the Romanian social tourism, referring to the spa tourism sector. Beside the elaboration of strategies, the Tourism Ministry made recent media declarations and press releases announcing spa and medical tourism as a priority field to be invested in.

The 2009 Master Plan for Spa Tourism Development found necessary for Romania, in the first place, to choose one or more marketing positions for its spa tourism sector and to elaborate based on market and offer analyses, suitable strategies. The next objectives regard the design of strategies to be applied on each combination product/market and the identification of financial means and work methods for their implementation. Considering the international spa tourism market trends and analyzing the characteristics of the Romanian balneal tourism, specialists identified as the market segments to be developed the "thermal cities", the anti-ageing treatment spa resorts, the traditional spa tourism sector and rehabilitation packages in spa destinations. Several resorts, spread on the whole Romanian territory, were mentioned as potential successful examples and priority centers for each of the mentioned spa tourism segments, able to offer and develop appropriate internationally recognized techniques. Therefore, Bucharest and Snagov, Mangalia or Techirghiol, Covasna and Sovata were identified as potential competitive destinations for the anti-ageing treatment within the spa market segment.

The concept of "thermal cities" identified suitable actors in each part of the Romanian territory, and specialists mentioned as illustrative examples to become priority resorts Vatra Dornei and Băile Herculane for medical cures, Sovata, Băile Felix,
Slănic Moldova, Snagov for recovery treatments and health care cures, Mangalia and Constanţa for thalasotherapy. The thermal centres offering spa packages, the littoral resorts offering thalassotherapy and the green resorts offering spa treatments as well as fitness and rehabilitation cures should focus on a global strategy integrating both private stakeholders, who should be stimulated to invest in health infrastructure and accommodation structures, and public stakeholders who should take care of planning and animating the cities through different programmes.

Interesting target markets for this segment could be Central Europe and Ucraine/Rusia, as developing markets, which could bring an important added value. Medical tourism focusing on cosmetic anti ageing treatments or cures against obesity, tobacco addiction, etc. implies important private investments and needs a punctual approach on clinics and treatments and should focus on target markets in the developed world such as Western Europe and USA as this spa segment generally orients towards niche markets in full development and characterized by an important added value. The traditional balneal tourism sector, still dominated to a great extent by social tourism and present at the level of all Romanian spa resorts, is considered to be less effective as the social spa tourism and social insurance systems are in decline at the worldwide level. Still this offer would be attractive for internal clientele as Romanians have the balneal culture and people prefer close destinations when their health is concerned. On this segment, a global resort approach should be applied, mainly based on public investments which should focus on standards' appraisal and the adopting of a diversified product and price strategy in order to satisfy internal demand.

However, all Romanian spa resorts could be characterized as thermal centers with ludic character offering packages with traditional spa tourism facilities and developing their leisure infrastructure in the attempt to attract more diversified clients. In this regard, according to experts, their marketing strategy should be carefully revised as worldwide examples of thermal centers with ludic character developed in spa resorts proved in many cases not to be a viable solution. Another segment to be considered for Romanian spa tourism, refers to rehabilitation cures and spa/fitness packages in the urban environment implying a punctual approach on spa centers based on private investments inside or independent of hotels and which should focus on urban national centers. Finally, the strategy proposed two major objectives. The first is to restore the credibility of tourism demand in the network of health centers, through laws and the regulation framework, professional training for medical care and for tourism 
services (especially for animation in tourism at the level of spa resorts), through testing and advertising the therapeutic value of balneal treatments. The second objective proposed by the strategy would be to develop appropriate priority combinations product/market based on the rehabilitation of social spa tourism and the concepts of "thermal cities", anti - ageing treatments or the diversification of spa segment with thalassotherapy, medical tourism or wellness packages etc. as already mentioned directions.

\section{Conclusions}

In conclusion, we may affirm that Romanian spa tourism, offering important and valuable resources and an important set of internally well-known balneal resorts, is a continuously transforming paradigm which registered a booming period during the communism epoch. Although profoundly transformed by the major political and socioeconomic changes which occurred after the Revolution in 1989, this sector inherited and is still dominated by elements coming from the socialist mass tourism period (e.g. mass hospitality structures, social systems of consume, etc.) which struggles to adapt and coexist with new emergent segments and forms of manifestation of spa tourism (e.g. medical tourism, cosmetic treatments), as present spa tourism industry orients itself towards new dimensions embraced by the present leisure consumerism and international tourism patterns.

\section{Acknowledgement}

The forth author acknowledges that this paper was supported by CNCSIS-UEFISCU, project number PN II-RU 94/2010, Contract no. 30/28.07.2010.

\section{Bibliography}

Détente Consultants, 2009, Action Plan for the Romanian Master Plan for the Development of Spa Tourism, $2^{\text {nd }}$ phase, http://www.detente.fr/

Détente Consultants, 2009, Romanian Master Plan for the Development of Spa Tourism, $2^{\text {nd }}$ phase, November 2009. http://www.detente.fr/

Détente Consultants, 2010, Calypso Study on Social Tourism - Romania, country study, http://www.detente.fr/

Dincă, AI 2008, Turism medical - concept și aplicabilitate în România, Comunicări de Geografie, Faculty of Geography, University of Bucharest, Tom XI, p. 385-39o.

Erdeli, G \& Gheorghilaș, A 2006, Amenajări turistice, Edit. Universitară, București.

Erdeli, G \& Istrate, I 1996, Amenajări turistice, Ed. Universității, București.

European Spa Industry, 2010, viewed January 2011, http://www.visitspas.eu/european-spa-industry/

Hudson, S (ed) 2003, Sport and Adventure Tourism, The Haworth Hospitality Press, New York.

INCDT, 2006, The strategy for Spa Tourism - Romania, The Ministry of Tourism. 